Sains Malaysiana 47(5)(2018): 931-940

http://dx.doi.org/10.17576/jsm-2018-4705-08

\title{
Pengoptimuman Kaedah dan Analisis Farmaseutik dalam Air Kumbahan dan Air Sungai
}

(Optimisation of Analytical Method and Analysis of Pharmaceuticals in Sewage and River Water)

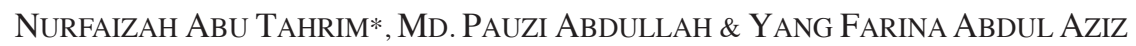

\begin{abstract}
ABSTRAK
Loji rawatan kumbahan (STP) sedia ada khususnya di Malaysia tidak direka untuk menyingkirkan bahan farmaseutik yang tergolong dalam kategori bahan cemar baru muncul. Oleh kerana farmaseutik yang hadir dalam persekitaran akuatik ialah pada kepekatan yang sangat rendah iaitu dalam julat bahagian per bilion dan trilion, satu kaedah pengekstrakan dan analisis yang peka perlu dibangunkan. Dalam kajian ini, kaedah analisis berdasarkan pengekstrakan fasa pepejal (SPE) diikuti dengan kromatografi cecair-spektrometri jisim masa penerbangan (LC-TOF-MS) menggunakan mod pengionan secara semburan elektro positif telah berjaya dibangunkan untuk menentukan kehadiran sepuluh farmaseutik terpilih dalam air kumbahan dan air sungai. Farmaseutik yang dikaji termasuk acetaminophen, theophylline, caffeine, metoprolol, sulfamethoxazole, carbamazepine, prednisolone, ketoprofen, norgestrel dan simvastatin. Kaedah SPE menggunakan langkah pengekstrakan tunggal yang menggunakan isi padu sampel yang rendah sebanyak $100 \mathrm{~mL}$ dan pelarut elusi yang minimum telah berjaya dicapai. Peratus perolehan semula untuk kesemua farmaseutik dalam sampel air sungai berada dalam julat 54-99\% manakala bagi sampel efluen STP pula berada dalam julat 57-96\%. Jangka masa analisis LC-TOF-MS termasuk masa imbangan adalah selama 25 min dengan menggunakan suntikan sampel $20 \mu L$. Prosedur SPE bersama-sama dengan kaedah analisis yang telah dibangunkan menghasilkan had kuantifikasi (LOQ) dalam lingkungan 0.031-0.882 $\mu \mathrm{g} / \mathrm{L}$ untuk sampel STP dan 0.030-0.926 $\mu \mathrm{g} / \mathrm{L}$ untuk sampel air sungai.
\end{abstract}

Kata kunci: Farmaseutik; loji rawatan kumbahan; pengekstrakan fasa pepejal (SPE)

\section{ABSTRACT}

Sewage treatment plants (STPS) particularly in Malaysia are not designed to eliminate pharmaceuticals which belong to the cate gory of emerging contaminants. Considering the levels of these contaminants could be incredibly low which are in the range of parts per billion and trillion in the aquatic environment, very sensitive analytical techniques and extraction methodologies have to be developed. In this present work, an analytical method based on solid phase extraction (SPE) followed by liquid chromatography-time-of-flight mass spectrometry (LC-TOF-MS) in positive electrospray ionisation mode was successfully developed to determine the presence of ten selected pharmaceuticals in aquatic environment. The compounds under study include acetaminophen, theophylline, caffeine, metoprolol, sulfamethoxazole, carbamazepine, prednisolone, ketoprofen, norgestrel and simvastatin. The SPE procedure was successfully achieved with a single extraction step using a low sample volume of $100 \mathrm{~mL}$ and minimum volume of eluting solvent. Percentage recovery for all pharmaceuticals in river water samples were in the range of 54-99\% while for STP effluent samples were in the range of 57-96\%. The total run time inclusive of equilibration in LC-TOF-MS analysis was 25 min with sample injection volume of $20 \mu \mathrm{L}$. The application of the optimised SPE procedure together with the instrumental analysis resulted in limit of quantification (LOQ) of $0.031-0.882 \mu \mathrm{g} / \mathrm{L}$ and $0.030-0.926 \mu \mathrm{g} / \mathrm{L}$ in STP and river water samples, respectively.

Keywords: Pharmaceuticals; sewage treatment plant; solid phase extraction (SPE)

\section{PENGENALAN}

Analisis dan penentuan bahan pencemaran alam sekitar masa ini tidak hanya memberi tumpuan kepada bahan pencemar klasik, malah telah dilanjutkan kepada bahan pencemaran yang baharu. Bahan pencemar alam sekitar baru muncul meliputi pelbagai jenis bahan kimia yang sebahagian besarnya adalah di luar skop pemantauan alam sekitar. Farmaseutik yang merujuk kepada ubat-ubatan preskripsi serta boleh didapati terus di kaunter farmasi atau di kedai untuk kegunaan manusia dan haiwan (US ${ }^{\circ} 2008$ ), tergolong dalam bahan pencemar alam sekitar baru muncul ini.
Farmaseutik direka untuk merangsang atau menghalang tindak balas fisiologi pada manusia dan haiwan. Walau bagaimanapun, mereka boleh memberi kesan buruk terhadap ekologi bukan sasaran dan organisme hidup apabila dilepaskan ke alam sekitar. Penemuan yang dibuat oleh Oropesa et al. (2016) mencadangkan bahawa carbamazepine boleh bertindak sebagai pengganggu endokrin pada Daphnia magna kerana ia mengurangkan keluaran reproduktif, mengganggu penentuan seks dan menyebabkan ketidaknormalan perkembangan pada anak. Oleh itu, bahan farmaseutik secara langsung boleh 
mempengaruhi kemampanan populasi. Terdapat juga laporan sejak kebelakangan ini yang menyatakan bahawa ubat-ubatan jenis analgesik ringan boleh menyebabkan pelbagai gangguan endokrin pada manusia (Albert et al. 2013). Kajian lanjut tentang toksikologi tahap surih farmaseutik dan bahan pencemar lain yang muncul di dalam air terhadap manusia perlu dilakukan untuk menentukan dengan tepat kesannya. Tambahan pula, farmaseutik hadir di alam sekitar dengan kombinasi sebatian farmaseutik lain, metabolit mereka bersama-sama dengan bahan pencemar alam sekitar yang lain. Walaupun kepekatan farmaseutik individu yang dikesan mungkin sangat rendah, masih tidak diketahui kesannya, jika ada, akibat pendedahan kepada dos campuran secara berulang terhadap kesihatan manusia. Pembuangan ubat-ubatan secara terus sama ada melalui pembuangan sampah, ke dalam tandas atau ke dalam sinki dapur menyumbang secara spesifik ke atas pertambahan kehadiran bahan farmaseutik dalam alam sekitar. Apabila kita mengambil ubat-ubatan pula, tidak semua ubat-ubatan ini akan dicerna seratus peratus dalam badan. Ubat-ubatan ini akan seterusnya keluar semasa proses perkumuhan melalui najis dan seterusnya akan disalurkan ke loji rawatan kumbahan (STP). Loji rawatan kumbahan yang sedia ada di kebanyakan negara termasuk Malaysia, tidak direka untuk mengurai ubat-ubatan ini. Kaedah yang digunakan adalah rawatan secara konvensional yang meliputi proses pengasingan, pengudaraan dan pemendapan. Selain itu rawatan sekunder kumbahan tertumpu kepada penyingkiran bahan organik terbiodegradasi dan pepejal terapung dan kebanyakannya menggunakan proses unit biologi dan penggunaan enapcemar teraktif. Walau bagaimanapun masih terdapat ubat-ubatan atau bahan farmaseutik dalam efluen air kumbahan ini yang tidak terurai dan akan dilepaskan ke dalam air sungai, yang akhirnya berkemungkinan untuk hadir di dalam air minum. Farmaseutik yang hadir dalam persekitaran akuatik ialah pada kepekatan yang sangat rendah, iaitu dalam julat bahagian per bilion dan per trilion. Sehubungan itu, satu kaedah pengekstrakan serta analisis yang peka dan mudah perlu dibangunkan. Setakat ini, masih belum ada satu kaedah piawai untuk menganalisis segala jenis bahan farmaseutik dalam persekitaran akuatik. Disebabkan kepelbagaian sifat fiziko-kimia yang dipamerkan oleh pelbagai kelas bahan farmaseutik tersebut, kebanyakan kaedah analisis yang telah dibangunkan memberi tumpuan kepada kumpulan yang khusus. Kaedah pengekstrakan fasa pepejal (SPE) masih banyak digunakan walaupun terdapat laporan kajian yang menggunakan kaedah pengekstrakan yang lain (Sanagi et al. 2013).

Dalam kajian ini, kaedah analisis berdasarkan SPE diikuti dengan LC-TOF-MS menggunakan mod pengionan secara semburan elektro positif dibangunkan untuk menentukan kehadiran sepuluh farmaseutik terpilih dalam persekitaran akuatik. Kaedah yang dibangunkan dalam kajian ini adalah berasaskan langkah pengekstrakan tunggal dan menggunakan isi padu sampel yang rendah serta pelarut yang minimum. Secara amnya farmaseutik yang dipilih tergolong dalam senarai yang diperoleh daripada National Essential Drugs List (2012) dan juga berdasarkan jenis ubat-ubatan yang kerap digunakan oleh penduduk Malaysia. Maklumat berkaitan diperoleh daripada senarai empat puluh teratas bagi ubat-ubatan yang banyak digunakan berdasarkan penggunaan Defined Daily Dose (DDD) untuk setiap 1000 populasi sehari di Malaysia (MOH 2014).

\section{BAHAN DAN KAEDAH}

\section{BAHAN KIMIA DAN BAHAN PIAWAI FARMASEUTIK}

Acetaminophen (No. CAS 103-90-2), caffeine (No. CAS 58-08-2), carbamazepine (No. CAS 298-46-4), ketoprofen (No. CAS 22071-15-4), metoprolol (No. CAS 56392-17-7), norgestrel (No. CAS 797-63-7), prednisolone (No. CAS 5024-8), simvastatin (No. CAS 79902-63-9), sulfamethoxazole (No. CAS 723-46-6) dan theophylline (No CAS 58-55-9) diperoleh daripada Sigma-Aldrich. Peratus ketulenan untuk kesemua bahan piawai farmaseutik yang digunakan adalah melebihi $98 \%$. Metanol $(\mathrm{MeOH})$ dan asetonitril (ACN) bergred HPLC, diklorometana, etil asetat (gred LC) dan asid formik dibekalkan oleh Merck. Metiltert-butileter (MTBE) diperoleh daripada J.T. Baker.

Larutan stok bagi setiap bahan piawai farmaseutik yang berkepekatan $1000 \mathrm{mg} / \mathrm{L}$ disediakan berasaskan berat sebatian farmaseutik dalam pelarut metanol bergred HPLC. Larutan campuran piawai yang mengandungi sepuluh jenis farmaseutik disediakan dengan cara pencairan setiap larutan stok bagi setiap bahan piawai farmaseutik tersebut. Larutan stok dan larutan campuran piawai ini disimpan di dalam botol amber penutup berskru di dalam peti sejuk beku pada suhu $<0^{\circ} \mathrm{C}$ untuk kegunaan seterusnya.

\section{PENGEKSTRAKAN FASA PEPEJAL}

Kaedah daripada beberapa kajian lepas telah dijadikan rujukan (Gonzalez-Barreiro et al. 2003; Petrovic et al. 2006; Vanderford \& Snyder 2006) sebagai asas pemilihan proses SPE dalam kajian ini. Walaupun banyak kaedah SPE telah dibangunkan namun hingga kini, masih tiada satu kaedah universal yang dapat mengekstrak semua jenis farmaseutik dalam satu masa dengan menghasilkan peratus perolehan semula yang baik untuk semua analit. Oleh itu, kaedah yang dirujuk masih lagi memerlukan proses pengoptimuman terutamanya dalam pemilihan pelarut kondisi dan elusi.

Katrij SPE yang digunakan dalam kajian ini ialah jenama Oasis HLB $3 \mathrm{~mL}$, yang berpadatan $60 \mathrm{mg}$ dan diperoleh daripada Waters, USA. Bahan padatan di dalam katrij tersebut ialah polimer universal fasa-berbalik yang telah dibangunkan untuk pengekstrakan pelbagai jenis bahan bersifat asid, bes dan neutral. Sebanyak $100 \mathrm{~mL}$ sampel terlebih dahulu dituras secara vakum menerusi kertas turas gentian kaca (GF/F glass microfiber) bersaiz liang $0.7 \mu \mathrm{m}$ (Whatman UK). Katrij SPE dipasang pada kebuk vakum SPE yang mempunyai 10 pangkalan. Pertama sekali, bahan penjerap fasa pepejal dalam katrij 
dikondisikan dengan $3 \mathrm{~mL}$ etil asetat, $3 \mathrm{~mL} \mathrm{MeOH}$ dan $3 \mathrm{~mL}$ air ternyahion secara berturutan. Sebanyak 100 $\mathrm{mL}$ sampel kemudian ditambahkan ke dalam katrij, tanpa diubah $\mathrm{pH}$, secara vakum pada kadar aliran $6 \mathrm{~mL} /$ min. Berikutnya, katrij tersebut dibilas dengan $3 \mathrm{~mL}$ air ternyahion dan seterusnya dibiarkan kering di bawah vakum selama 5 hingga 10 min untuk menyingkirkan air yang berlebihan. Tiub kaca $12 \mathrm{~mL}$ kemudian dimasukkan ke dalam kebuk SPE untuk mengumpul eluen. Bahan analit dielusi daripada penjerap dengan menggunakan $5 \mathrm{~mL}$ etil asetat ke dalam tiub kaca tersebut. Semasa langkah pengelusian dijalankan pam vakum dimatikan supaya pelarut boleh mengelusi secara tarikan graviti dan mengelusi dengan lebih berkesan. Pam vakum dihidupkan semula untuk memastikan semua pelarut telah melalui katrij tersebut. Pengeringan dan pemekatan eluen yang terhasil kemudian dijalankan di bawah aliran gas nitrogen. Akhir sekali, hasil ekstrak yang telah kering ditambahkan dengan $1 \mathrm{~mL} \mathrm{MeOH-air} \mathrm{ternyahion} \mathrm{(10:90,} \mathrm{v/v)} \mathrm{dan}$ dipindahkan ke dalam botol kaca amber daripada Agilent Technologies (USA) untuk dianalisis seterusnya.

\section{KROMATOGRAFI CECAIR - SPEKTROMETRI JISIM - MASA PENERBANGAN}

Pemisahan analit dijalankan menggunakan peralatan kromatografi cecair berjenama Dionex Ultimate 3000/ LC 09115047 (USA) yang dilengkapi dengan penyahgasan vakum, pam kuartenari dan autosampler diikuti dengan pengesanan analit menggunakan sistem TOF-MS keluaran syarikat Bruker Daltonics (Germany). Turus yang digunakan ialah turus $\mathrm{C} 18$ berjenama Thermo Scientific berukuran $250 \times 2.1 \mathrm{~mm}$ dan mempunyai diameter dalaman (I.D.) $5 \mu \mathrm{m}$. Dalam kajian ini, sepuluh farmaseutik yang dikaji, dianalisis dalam mod semburan elektro positif (ESI+). Berikut adalah parameter yang ditetapkan sepanjang analisis menggunakan instrumen tersebut: voltan kapilari, $4000 \mathrm{~V}$; kadar aliran gas, 8.0 L/min; tekanan nebulizer, 4.0 Bar dan suhu, $190^{\circ} \mathrm{C}$.

Jangka masa analisis termasuk masa imbangan adalah selama 25 min dengan menggunakan isi padu suntikan sampel $20 \mu \mathrm{L}$. Program kecerunan elusi terbaik yang diperoleh ialah dengan menggunakan set pelarut fasa bergerak berikut: (A) $0.1 \%$ asid formik dalam air ternyahion dan (B) $100 \%$ ACN pada kadar alir $0.3 \mathrm{~mL} /$ min. Program kecerunan elusi tersebut dimulakan dengan $5 \%$ eluen B, dinaikkan kepada $50 \%$ dalam 8 min dan ditingkatkan seterusnya kepada $95 \%$ pada kecerunan 3 min. Keadaan ini dibiarkan selama $5.5 \mathrm{~min}$. Program kecerunan ini dikembalikan kepada $5 \%$ eluen B pada min ke 16.7 dan dibiarkan malar selama 8.3 min untuk mencapai keseimbangan sebelum suntikan seterusnya. Penyuntik dibilas secara automatik dengan $\mathrm{MeOH}$ setiap kali selepas suntikan dilakukan. Data jisim tepat untuk ion-ion analit diproses melalui perisian Bruker Daltonics Data Analysis, yang memberikan komposisi unsur dan ralat jisim. Nilai $\mathrm{m} / \mathrm{z}$ untuk analit sasaran diekstrak daripada kromatogram ion jumlah (TIC) untuk menghasilkan ukuran jisim yang tepat untuk setiap satu analit tersebut. Semua analit kecuali simvastatin memaparkan penerimaan $\mathrm{H}^{+}$ lalu mengasilkan $[\mathrm{M}+\mathrm{H}]^{+}$dalam mod pengionan ESI positif. Simvastatin dikenal pasti dengan lebih berkesan menggunakan aduk sodium, $[\mathrm{M}+\mathrm{Na}]^{+} \mathrm{C}_{25} \mathrm{H}_{38} \mathrm{NaO}_{5}$. Rajah 1 ialah contoh kromatogram ion jumlah yang menunjukkan pemisahan sepuluh bahan piawai menggunakan mod ESI positif tanpa menjalani proses SPE. Jadual 1 menunjukkan masa penahanan dan ukuran jisim tepat bagi farmaseutik sasaran dalam larutan piawai. Jisim ralat yang diperoleh untuk kesemua analit tidak melebihi 3.6 ppm.

\section{KUANTIFIKASI DAN VALIDASI KAEDAH}

Keberkesanan kaedah pengekstrakan dinilai dengan menentukan peratus perolehan semula setiap analit. 20 $\mu \mathrm{L}$ larutan campuran piawai berkepekatan 10 ppm yang mengandungi kesepuluh bahan farmaseutik dimasukkan ke dalam sampel air di dalam kelalang isi padu $100 \mathrm{~mL}$ bagi menghasilkan kepekatan akhir $2 \mu \mathrm{g} / \mathrm{L}$. Sampel air kemudian diekstrak dengan menggunakan kaedah SPE yang telah dioptimumkan. Hasil ekstrak yang telah kering ditambahkan dengan $1 \mathrm{~mL} \mathrm{MeOH}$-air ternyahion (10:90, v/v) dan dipindahkan ke dalam botol kaca amber daripada Agilent Technologies (USA) untuk dianalisis menggunakan

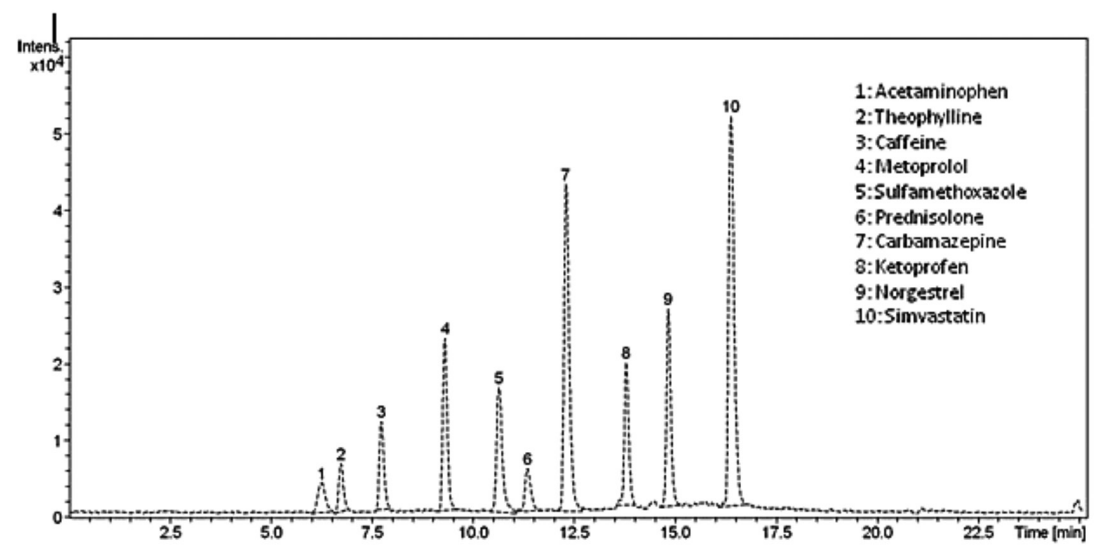

RAJAH 1. Kromatogram ion jumlah bagi kesepuluh bahan piawai farmaseutik terpilih 
JADUAL 1. Masa penahanan dan ukuran jisim tepat bagi farmaseutik sasaran dalam larutan piawai

\begin{tabular}{|c|c|c|c|c|c|c|c|}
\hline $\begin{array}{c}\text { No. } \\
\text { Puncak }\end{array}$ & Farmaseutik & $\begin{array}{c}\text { Masa } \\
\text { penahanan } \\
(\min )\end{array}$ & Komposisi unsur & $\begin{array}{c}\text { Jisim } \\
\text { eksperimen }\end{array}$ & Jisim teori & $\begin{array}{l}\text { Ralat } \\
(\mu \mathrm{Da})\end{array}$ & $\begin{array}{l}\text { Ralat } \\
\text { (ppm) }\end{array}$ \\
\hline 1 & Acetaminophen & 6.40 & {$[\mathrm{M}+\mathrm{H}]^{+} \mathrm{C}_{8} \mathrm{H}_{10} \mathrm{NO}_{2}$} & 152.0706 & 152.0712 & 0.000549 & 3.61 \\
\hline 2 & Theophylline & 6.79 & {$[\mathrm{M}+\mathrm{H}]^{+} \mathrm{C}_{7} \mathrm{H}_{9} \mathrm{~N}_{4} \mathrm{O}_{2}$} & 181.0720 & 181.0726 & 0.000549 & 3.03 \\
\hline 3 & Caffeine & 7.80 & {$[\mathrm{M}+\mathrm{H}]^{+} \mathrm{C}_{8} \mathrm{H}_{11} \mathrm{~N}_{4} \mathrm{O}_{2}$} & 195.0877 & 195.0882 & 0.000549 & 2.81 \\
\hline 4 & Metoprolol & 9.30 & {$[\mathrm{M}+\mathrm{H}]^{+} \mathrm{C}_{15} \mathrm{H}_{26} \mathrm{NO}_{3}$} & 268.1907 & 268.1913 & 0.000549 & 2.05 \\
\hline 5 & Sulfamethoxazole & 10.69 & {$[\mathrm{M}+\mathrm{H}]^{+} \mathrm{C}_{10} \mathrm{H}_{12} \mathrm{~N}_{3} \mathrm{O}_{3} \mathrm{~S}$} & 254.0594 & 254.0599 & 0.000549 & 2.16 \\
\hline 6 & Prednisolone & 11.70 & {$[\mathrm{M}+\mathrm{H}]^{+} \mathrm{C}_{21} \mathrm{H}_{29} \mathrm{O}_{5}$} & 361.2010 & 361.2015 & 0.000549 & 1.52 \\
\hline 7 & Carbamazepine & 12.34 & {$[\mathrm{M}+\mathrm{H}]^{+} \mathrm{C}_{15} \mathrm{H}_{13} \mathrm{~N}_{2} \mathrm{O}$} & 237.1022 & 237.1028 & 0.000549 & 2.32 \\
\hline 8 & Ketoprofen & 13.80 & {$[\mathrm{M}+\mathrm{H}]^{+} \mathrm{C}_{16} \mathrm{H}_{15} \mathrm{O}_{3}$} & 255.1016 & 255.1021 & 0.000548 & 2.15 \\
\hline 9 & Norgestrel & 14.90 & {$[\mathrm{M}+\mathrm{H}]^{+} \mathrm{C}_{21} \mathrm{H}_{29} \mathrm{O}_{2}$} & 313.2162 & 313.2168 & 0.000548 & 1.75 \\
\hline 10 & Simvastatin & 16.41 & {$[\mathrm{M}+\mathrm{Na}]^{+} \mathrm{C}_{25} \mathrm{H}_{38} \mathrm{NaO}_{5}$} & 441.2792 & 441.2797 & 0.000548 & 1.24 \\
\hline
\end{tabular}

LC-TOF-MS. Langkah ini dijalankan ke atas sampel air sungai dan air rawatan kumbahan. Peratus perolehan semula (\% R) untuk setiap jenis sampel air dikira dengan menggunakan persamaan yang diadaptasi daripada Laven et al. (2009) seperti berikut:

$\% \mathrm{R}=\frac{\text { Luas puncak (pakuan sebelum) }- \text { Luas puncak (tanpa pakuan) }}{\text { Luas puncak (pakuan selepas) }- \text { Luas puncak (tanpa pakuan) }}$

Had pengesanan instrumen (IDL) dan had kuantifikasi instrumen (IQL) ditentukan dengan menyuntik secara terus larutan campuran piawai dengan penurunan kepekatan ke sistem LC-TO-MS yang telah dioptimumkan. Nilai IDL untuk setiap bahan farmaseutik dianggarkan dengan melihat kepada bacaan nisbah isyarat bising $(\mathrm{S} / \mathrm{N})$, dengan nilai $\mathrm{S} / \mathrm{N} \geq 3$ manakala $\mathrm{S} / \mathrm{N} \geq 10$ untuk IQL. Had kuantifikasi (LOQ) bagi keseluruhan kaedah SPE diikuti dengan LC-TOFMS untuk setiap bahan farmaseutik dalam sesuatu matriks dikira dengan menggunakan persamaan berikut:

$$
\mathrm{LOQ}=\frac{\mathrm{IQL} \times 100}{\% \mathrm{R} \times \mathrm{CF}}
$$

dengan IQL ialah had kuantifikasi instrument, \% R bermaksud peratus perolehan semula analit dalam matriks tersebut dan CF ialah faktor kepekatan (Vieno et al. 2006).

\section{PENSAMPELAN DAN ANALISIS SAMPEL SEBENAR}

Pensampelan bagi sampel air kumbahan dijalankan di loji rawatan kumbahan yang terletak di Pantai Dalam, Kuala Lumpur. Pensampelan bagi sampel air sungai dijalankan di tiga stesen, iaitu sebelum dan selepas kawasan pelepasan efluen air kumbahan di Sungai Klang dan satu lagi stesen pensampelan di Sungai Kerayong. Jadual 2 menunjukkan penerangan secara ringkas stesen-stesen pensampelan yang dipilih.

Sampel STP dan air sungai diambil dengan menggunakan baldi keluli atau terus dengan botol kaca yang dibilas beberapa kali dengan air sampel. Air sampel kemudian dipindahkan ke dalam botol kaca $500 \mathrm{~mL}$ bertutup polipropilena yang sebelumnya juga telah dibilas dengan air sampel. Botol-botol tersebut diletakkan di dalam kotak sejuk berisi pek ais untuk dibawa ke makmal. Sebanyak $0.5 \mathrm{~g}$ sodium azida untuk setiap $500 \mathrm{~mL}$ sampel dimasukkan ke dalam botol sampel untuk tujuan pengawetan.

JADUAL 2. Penerangan secara ringkas stesen-stesen pensampelan

\begin{tabular}{cc}
\hline $\begin{array}{c}\text { Stesen } \\
\text { Pensampelan }\end{array}$ & Penerangan \\
\hline RS & $\begin{array}{c}\text { Kolam kumbahan belum dirawat } \\
\text { PC }\end{array}$ \\
KE & $\begin{array}{r}\text { Kolam penjernihan peringkat pertama di mana serpihan batu-batu dan pasir, serta } \\
\text { bahan-bahan lain seperti botol, plastik dan pepejal terampai telah disingkirkan } \\
\text { Kolam efluen terawat }\end{array}$ \\
S1 & Sungai Klang, $200 \mathrm{~m}$ sebelum tempat pelepasan efluen STP \\
S2 & $\left(3^{\circ} 05^{\prime} 53.87^{\prime \prime} \mathrm{N}, 101^{\circ} 40^{\prime} 24.78^{\prime \prime}\right.$ E) \\
Sungai Klang, $450 \mathrm{~m}$ selepas tempat pelepasan efluen STP \\
S3 & $3^{\circ} 05^{\prime} 36.64^{\prime \prime} \mathrm{N}, 101^{\circ} 40^{\prime} 19.16^{\prime \prime}$ E) \\
& Sungai Kerayong, $100 \mathrm{~m}$ daripada pertemuan dengan Sungai Klang \\
$\left(3^{\circ} 05^{\prime} 51.08^{\prime \prime} \mathrm{N}, 101^{\circ} 40^{\prime} 27.27^{\prime \prime} \mathrm{E}\right)$
\end{tabular}




\section{KEPUTUSAN DAN PERBINCANGAN}

\section{PENGOPTIMUMAN KAEDAH PENGEKSTRAKAN} FASA PEPEJAL

Isi padu sampel sebanyak 50, 100 dan 200 mL digunakan dalam pengoptimuman ini. Rajah 2 menunjukkan peratus perolehan semula yang didapati apabila tiga jumlah isi padu kemasukan sampel digunakan semasa proses pengoptimuman. Penggunaan isi padu sampel sebanyak $100 \mathrm{~mL}$ menunjukkan nilai purata peratus perolehan semula yang tertinggi iaitu $85 \%$. Isi padu sampel $50 \mathrm{~mL}$ dan $200 \mathrm{~mL}$ pula mempunyai peratus perolehan semula masing-masing sebanyak $62 \%$ dan 54\%. Ujian statistik menggunakan analisis varians (ANOVA) menunjukkan bahawa terdapat perbezaan yang nyata $(p<0.05)$ bagi nilai purata peratus perolehan semula pada tiga isi padu kemasukan sampel tersebut.

Rajah 3 menunjukkan peratus perolehan semula untuk setiap satu bahan farmaseutik pada $\mathrm{pH}$ berasid $(\mathrm{pH}$ = 2) dan untuk sampel yang tidak dilakukan pelarasan pH. Keputusan yang diperoleh dalam kajian ini selari dengan keputusan kajian yang dijalankan oleh Gros et al. (2006) dan Al-Qaim et al. (2014) yang juga menggunakan katrij Oasis HLB. Tanpa sebarang pelarasan $\mathrm{pH}$, peratus perolehan semula didapati dalam julat 44 hingga $138 \%$ manakala pada keadaan berasid pula dalam julat 7 hingga $177 \%$. Carbamazepine tergolong dalam kategori farmaseutik bersifat neutral (Vieno et al. 2006), oleh itu ubah suai $\mathrm{pH}$ larutan sampel tidak mempunyai kesan yang ketara terhadap perolehan semula analit tersebut. Peratus perolehan semula bagi carbamazepine ialah $105 \%$ tanpa pelarasan $\mathrm{pH}$ dan $101 \%$ pada $\mathrm{pH} 2$. Ujian ANOVA tidak menunjukkan perbezaan yang signifikan antara perubahan $\mathrm{pH}(p>0.05)$. Oleh kerana kajian ini bertujuan untuk mengekstrak sepuluh analit sasaran sekaligus dalam satu langkah SPE, proses SPE tanpa sebarang pelarasan $\mathrm{pH}$ ke atas sampel dipilih berdasarkan peratus perolehan semula secara keseluruhan dalam julat yang baik untuk kesemua farmaseutik.

Set pelarut untuk langkah elusi yang dibandingkan semasa proses pengoptimuman terdiri daripada etil asetat dan dikombinasi dengan pelbagai pelarut lain seperti

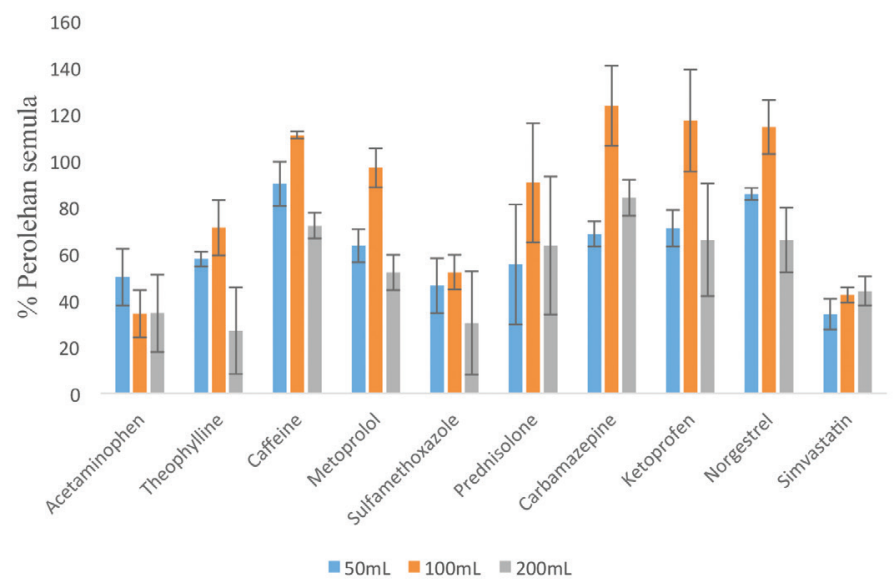

RAJAH 2. Peratus perolehan semula pada tiga isi padu kemasukan sampel berbeza

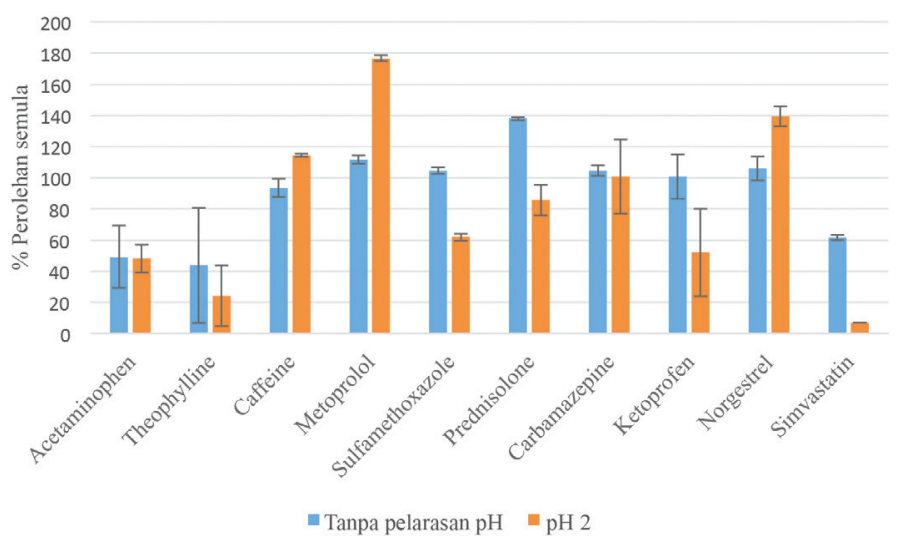

RAJAH 3. Pengaruh $\mathrm{pH}$ sampel terhadap peratus perolehan semula bahan farmaseutik

Series 1: $\mathrm{MeOH}+\mathrm{MTBE}+$ etil asetat; Series 2: $\mathrm{MeOH}+\mathrm{MTBE}+$ etil asetat (sedikit pengubahsuaian pada langkah kondisi); Series 3: Etil asetat; Series 4: MTBE + etil asetat; Series 5: MeOH + etil asetat + diklorometana 
$\mathrm{MeOH}$, MTBE dan diklorometana. Peratus perolehan semula bagi kesemua farmaseutik untuk setiap set pelarut elusi ditunjukkan dalam Rajah 4. Dalam kajian ini, etil asetat didapati dapat mengelusi bahan farmaseutik secara paling berkesan berbanding dengan pelarut yang lain. Nilai purata peratus perolehan semula bagi bahan farmaseutik menggunakan pelarut etil asetat ialah sebanyak $72 \%$. Etil asetat yang tergolong dalam kumpulan ester mempunyai kekutuban yang tidak jauh berbeza daripada diklorometana. Ia dikategorikan sebagai sempadan pelarut aprotik berkutub. Pelarut dalam kategori ini mempunyai pemalar dielektrik yang agak tinggi daripada pelarut tidak berkutub. Oleh kerana ia mempunyai kekutuban tahap pertengahan, ia adalah pelarut yang baik untuk pelbagai jenis tindak balas. Bahan farmaseutik terpilih dalam kajian ini juga meliputi jenis kekutuban yang berbeza. Oleh kerana kaedah SPE dalam kajian ini melibatkan pengelusian secara sekaligus, etil asetat didapati sesuai dengan sifat kekutubannya yang tidak terlalu tinggi.

\section{VALIDASI KAEDAH KESELURUHAN}

Setiap bahan farmaseutik dalam sampel dikenal pasti menerusi nilai nisbah jisim kepada cas $(\mathrm{m} / \mathrm{z})$ dan masa penahanan bahan tersebut yang dibandingkan dengan nilai bagi bahan piawai.

Perolehan semula dalam kaedah SPE adalah spesifik kepada analit dan juga spesifik kepada matrik yang terlibat. Oleh itu dalam kajian ini peratus perolehan semula divalidasikan untuk keseluruhan kaedah. Perolehan semula juga berperanan untuk menilai keberkesanan katrij HLB dalam mengekstrak farmaseutik terpilih secara sekaligus. Jadual 3 menunjukkan peratus perolehan semula pada aras kemasukkan kepekatan larutan piawai campuran $2 \mu \mathrm{g} / \mathrm{L}$ dalam $100 \mathrm{~mL}$ sampel efluen STP dan air sungai. Dalam jadual tersebut dapat dilihat bahawa peratus perolehan semula bagi sampel air sungai berada dalam julat $54 \%$ hingga 99\% dengan nilai SD dalam julat 3-9 $\mu \mathrm{g} / \mathrm{L}$ untuk tiga ulangan sampel. Bagi sampel efluen STP pula peratus perolehan semula yang diperoleh berada dalam julat 57-

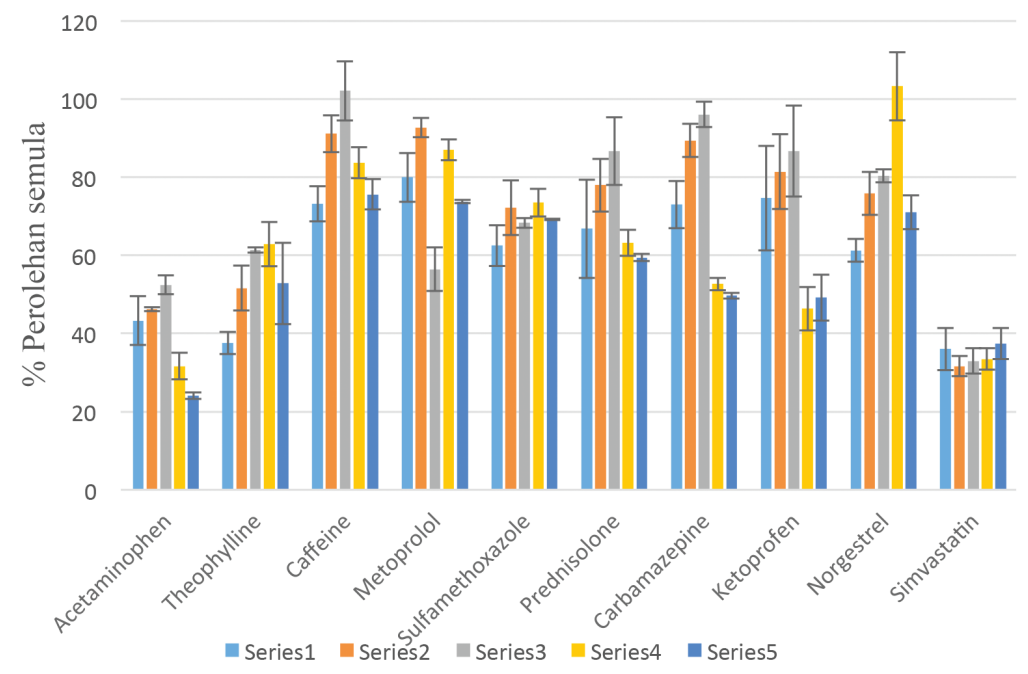

RAJAH 4. Peratus perolehan semula pada lima set pelarut elusi

JADUAL 3. Peratus perolehan semula (absolute recoveries) pada aras kemasukkan kepekatan larutan piawai campuran $2 \mu \mathrm{g} / \mathrm{L}$ dalam $100 \mathrm{~mL}$ sampel efluen STP dan air sungai

\begin{tabular}{|c|c|c|c|c|c|c|}
\hline \multirow[b]{3}{*}{ Farmaseutik } & \multicolumn{6}{|c|}{$\%$ Perolehan semula } \\
\hline & \multicolumn{3}{|c|}{ Air sungai } & \multicolumn{3}{|c|}{ Efluen STP } \\
\hline & & $\begin{array}{c}\text { SD } \\
(n=3)\end{array}$ & $\%$ RSD & & $\begin{array}{c}\text { SD } \\
(n=3)\end{array}$ & $\%$ RSD \\
\hline Acetaminophen & 54 & 3 & 6 & 57 & 13 & 22 \\
\hline Theophylline & 69 & 5 & 7 & 66 & 10 & 12 \\
\hline Caffeine & 95 & 5 & 6 & 95 & 3 & 3 \\
\hline Metoprolol & 85 & 8 & 9 & 88 & 3 & 3 \\
\hline Sulfamethoxazole & 68 & 6 & 8 & 87 & 4 & 4 \\
\hline Prednisolone & 94 & 6 & 6 & 96 & 4 & 5 \\
\hline Carbamazepine & 99 & 5 & 5 & 90 & 6 & 7 \\
\hline Ketoprofen & 64 & 6 & 10 & 80 & 5 & 6 \\
\hline Norgestrel & 88 & 9 & 10 & 79 & 4 & 5 \\
\hline Simvastatin & 67 & 5 & 7 & 64 & 3 & 4 \\
\hline
\end{tabular}


96\% dengan nilai SD 3-13 $\mu \mathrm{g} / \mathrm{L}$ untuk tiga ulangan sampel. Acetaminophen menunjukkan peratus perolehan semula yang terendah berbanding dengan bahan farmaseutik yang lain dalam kedua-dua sampel air sungai dan efluen STP. Walau bagaimanapun, perolehan semula yang rendah bagi acetaminophen adalah setanding dengan keputusan yang dilaporkan oleh kajian terdahulu (Al-Odaini et al. 2010; Tan et al. 2015).

Kelinearan bagi satu pemiawaian luaran menggunakan larutan campuran piawai bahan farmaseutik dalam $\mathrm{MeOH}$ dinilai melalui nilai pekali regresi, R2 graf tersebut. Nilai yang diperoleh ditunjukkan dalam Jadual 4. Nilai IDL untuk setiap bahan farmaseutik ditentukan dengan melihat kepada bacaan $\mathrm{S} / \mathrm{N} \geq 3$ manakala $\mathrm{S} / \mathrm{N} \geq 10$ untuk IQL menerusi penurunan kepekatan larutan campuran piawai. Nilai IDL yang diperoleh berada dalam julat $0.5-7.5 \mu \mathrm{g} / \mathrm{L}$ dengan carbamazepine, ketoprofen dan simvastatin menunjukkan sensitiviti yang paling tinggi. Suntikan sampel yang digunakan ialah sebanyak $20 \mu \mathrm{L}$. Nilai IQL pula diperoleh dalam julat 2 - $50 \mu \mathrm{g} / \mathrm{L}$. Bagi efluen STP nilai LOQ berada dalam julat $0.031-0.882 \mu \mathrm{g} / \mathrm{L}$ manakala bagi air sungai pula nilai LOQ berada dalam julat $0.030-0.926 \mu \mathrm{g} / \mathrm{L}$. Kesemua nilai LOQ dipaparkan dalam Jadual 5. Simvastatin menunjukkan nilai LOQ yang terendah dalam kedua-dua jenis matrik sampel. Nilai LOQ yang rendah amat penting dalam kajian farmaseutik dalam air ini kerana kajian ini melibatkan analisis kehadiran analit pada tahap surih.

\section{ANALISIS SAMPEL SEBENAR}

Kajian farmaseutik dalam persekitaran akuatik telah semakin mendapat perhatian para penyelidik di Malaysia namun masih agak terhad (Al-Odaini et al. 2010; AlQaim et al. 2016; Tan et al. 2015). Matrik sampel yang dikaji meliputi sampel air sungai, influen dan efluen STP serta influen dan efluen hospital. Kajian ini melibatkan pensampelan di STP dan air sungai. Kehadiran farmaseutik sasaran dalam sampel air kumbahan dan air sungai dalam kajian ini ditunjukkan dalam Jadual 6 dan 7.

Untuk sampel loji rawatan kumbahan, empat bahan farmaseutik hadir secara konsisten di ketiga-tiga lokasi persampelan iaitu acetaminophen, theophylline, caffeine dan metoprolol. Kehadiran bahan-bahan ini berkurangan daripada air kumbahan belum terawat apabila menjadi efluen terawat. Kehadiran tertinggi dikesan ialah pada air kumbahan belum terawat iaitu acetaminophen pada nilai maksimum $26.80 \mu \mathrm{g} / \mathrm{L}$, theophylline pada nilai 14.84 $\mu \mathrm{g} / \mathrm{L}$, caffeine pada nilai $30.89 \mu \mathrm{g} / \mathrm{L}$ dan metoprolol pada nilai $1.90 \mu \mathrm{g} / \mathrm{L}$. Kekerapan dan jumlah kepekatan dijumpai dalam efluen terawat bagi acetaminophen dan caffeine menurun. Ini memberi gambaran bahawa acetaminophen dan caffeine boleh terurai semasa proses rawatan di STP, namun masih tidak boleh disingkirkan sepenuhnya. Keputusan yang diperoleh ini sepadan dengan yang diperoleh oleh Tan et al. (2015). Sebaliknya, peratus kekerapan dikesan untuk theophylline masih juga tinggi

JADUAL 4. Kelinearan bahan piawai farmaseutik

\begin{tabular}{lccc}
\hline Farmaseutik & $\begin{array}{c}\text { Julat kelinearan }(\mu \mathrm{g} / \mathrm{L}) \\
\text { (Bilangan titik) }\end{array}$ & Persamaan & Nilai $\mathrm{R}^{2}$ \\
\hline Acetaminophen & $50-800(5)$ & $\mathrm{y}=105.08 \mathrm{x}+6654$ & 0.9926 \\
Theophylline & $20-800(6)$ & $\mathrm{y}=256.82 \mathrm{x}+6911.1$ & 0.9919 \\
Caffeine & $20-800(5)$ & $\mathrm{y}=363.02 \mathrm{x}+12311$ & 0.9957 \\
Metoprolol & $15-500(5)$ & $\mathrm{y}=577.65 \mathrm{x}+5620.8$ & 0.9994 \\
Sulfamethoxazole & $10-500(6)$ & $\mathrm{y}=670.43 \mathrm{x}+7014$ & 0.9967 \\
Prednisolone & $50-400(5)$ & $\mathrm{y}=119.74 \mathrm{x}+4056.9$ & 0.9898 \\
Carbamazepine & $5-800(5)$ & $\mathrm{y}=700.66 \mathrm{x}+8250.2$ & 0.9997 \\
Ketoprofen & $5-500(5)$ & $\mathrm{y}=633.09 \mathrm{x}+9775.7$ & 0.9979 \\
Norgestrel & $7.5-500(5)$ & $\mathrm{y}=976.07 \mathrm{x}-3148.9$ & 0.9991 \\
Simvastatin & $2-500(7)$ & $\mathrm{y}=1948.9 \mathrm{x}+15764$ & 0.9986 \\
\hline
\end{tabular}

JADUAL 5. Nilai LOQ untuk setiap bahan farmaseutik dalam kajian ini

\begin{tabular}{|c|c|c|c|c|c|c|}
\hline \multirow{2}{*}{ Farmaseutik } & \multirow[t]{2}{*}{$\operatorname{IQL}(\mu \mathrm{g} / \mathrm{L})$} & \multicolumn{2}{|c|}{$\%$ Perolehan semula } & \multirow{2}{*}{$\mathrm{CF}$} & \multicolumn{2}{|c|}{$\mathrm{LOQ}(\mu \mathrm{g} / \mathrm{L})$} \\
\hline & & Sampel STP & Air sungai & & STP & Air sungai \\
\hline Acetaminophen & 50 & 57 & 54 & 100 & 0.882 & 0.926 \\
\hline Theophylline & 20 & 66 & 69 & 100 & 0.305 & 0.290 \\
\hline Caffeine & 20 & 95 & 95 & 100 & 0.210 & 0.211 \\
\hline Metoprolol & 15 & 88 & 85 & 100 & 0.171 & 0.176 \\
\hline Sulfamethoxazole & 10 & 87 & 68 & 100 & 0.115 & 0.147 \\
\hline Prednisolone & 50 & 96 & 94 & 100 & 0.520 & 0.532 \\
\hline Carbamazepine & 5 & 90 & 99 & 100 & 0.056 & 0.051 \\
\hline Ketoprofen & 5 & 80 & 64 & 100 & 0.062 & 0.078 \\
\hline Norgestrel & 7.5 & 79 & 88 & 100 & 0.095 & 0.085 \\
\hline Simvastatin & 2 & 64 & 67 & 100 & 0.031 & 0.030 \\
\hline
\end{tabular}


iaitu $80 \%$ pada sampel di efluen terawat. Daripada Jadual 6 dapat diperhatikan bahawa kekerapan carbamazepine, metoprolol dan sulfamethoxazole ditemui dalam efluen terawat lebih tinggi daripada dalam air yang belum dirawat. Ini berkemungkinan bahawa bahan farmaseutik tersebut boleh bertaut semula selepas proses penguraian oleh bakteria. Hal yang sama pernah diutarakan dalam kajian oleh Bienkowski (2015).

Untuk sampel air sungai pula, tujuh bahan farmaseutik dikesan sekurang-kurangnya sekali sepanjang persampelan di ketiga-tiga sungai iaitu acetaminophen, theophylline, caffeine, metoprolol, ketoprofen, norgesterel dan simvastatin. Daripada keputusan kajian yang diperoleh, didapati prednisolone tidak dapat dikesan dalam kesemua sampel. Ini berkemungkinan disebabkan oleh nilai LOQ untuk prednisolone ini agak tinggi, iaitu $0.520 \mu \mathrm{g} / \mathrm{L}$ untuk STP dan $0.532 \mu \mathrm{g} /$ Luntuk air sungai. Kehadiran prednisolone dalam persekitaran (jika ada) mungkin pada kepekatan yang amat surih menjadikan ianya tidak dapat dikesan dengan had kuantifikasi tersebut. Pada masa yang sama kajian terhadap kehadiran prednisolone dalam persekitaran akuatik di Malaysia juga tidak pernah dilaporkan setakat ini. Selain daripada segi jumlah penggunaan dalam kalangan penduduk, prednisolone, berkemungkinan lebih berkesan jika dianalisis menggunakan mod pengionan yang lain dalam LC-TOF-MS seperti mod pengionan kimia secara tekanan atmosfera (APCI) berbanding dengan mod ESI, yang lebih sesuai jika sifat kekutuban molekul tersebut tidak terlalu tinggi.

Walaupun nilai LOQ bagi acetaminophen adalah lebih tinggi daripada nilai LOQ prednisolone, iaitu 0.882 $\mu \mathrm{g} / \mathrm{L}$ bagi STP dan $0.926 \mu \mathrm{g} / \mathrm{L}$ bagi air sungai, namun acetaminophen masih boleh dikesan menggunakan kaedah analisis yang dibangunkan dalam kajian ini. Berbanding dengan prednisolone, penggunaan bahan farmaseutik ini adalah lebih meluas dalam kalangan penduduk Malaysia. Acetaminophen juga tergolong dalam ubatan over-thecounter (OTC) yang mudah dibeli oleh orang awam.

JADUAL 6. Kehadiran farmaseutik sasaran sepanjang tempoh persampelan air kumbahan $(\mathrm{n}=15)$

\begin{tabular}{|c|c|c|c|c|c|c|}
\hline \multicolumn{7}{|c|}{ Kehadiran farmaseutik di STP $(n=15)$} \\
\hline \multirow[b]{2}{*}{ Farmaseutik } & \multicolumn{2}{|c|}{$\begin{array}{c}\text { Air kumbahan belum } \\
\text { dirawat }\end{array}$} & \multicolumn{2}{|c|}{$\begin{array}{c}\text { Kolam penjernihan peringkat } \\
\text { pertama }\end{array}$} & \multicolumn{2}{|c|}{ Efluen terawat } \\
\hline & $\begin{array}{c}\operatorname{Max} \\
(\mu \mathrm{g} / \mathrm{L})\end{array}$ & $\begin{array}{c}\text { Kekerapan } \\
\text { dikesan }(\%)\end{array}$ & $\operatorname{Max}(\mu \mathrm{g} / \mathrm{L})$ & $\begin{array}{c}\text { Kekerapan } \\
\text { dikesan }(\%)\end{array}$ & $\begin{array}{c}\operatorname{Max} \\
(\mu \mathrm{g} / \mathrm{L})\end{array}$ & $\begin{array}{r}\text { Kekerapan } \\
\text { dikesan }(\%)\end{array}$ \\
\hline Acetaminophen & 26.80 & $80 \%$ & 22.87 & $80 \%$ & 1.72 & $7 \%$ \\
\hline Theophylline & 14.84 & $80 \%$ & 12.43 & $80 \%$ & 6.06 & $80 \%$ \\
\hline Caffeine & 30.89 & $80 \%$ & 28.58 & $80 \%$ & 2.53 & $27 \%$ \\
\hline Metoprolol & 1.90 & $27 \%$ & 1.11 & $27 \%$ & 0.15 & $80 \%$ \\
\hline Sulfamethoxazole & $<$ LOQ & $13 \%$ & 0.32 & $20 \%$ & 0.11 & $60 \%$ \\
\hline Prednisolone & TD & $0 \%$ & 0.00 & $0 \%$ & $\mathrm{TD}$ & $0 \%$ \\
\hline Carbamazepine & TD & $0 \%$ & 0.00 & $0 \%$ & 0.15 & $53 \%$ \\
\hline Ketoprofen & TD & $0 \%$ & 0.00 & $0 \%$ & $\mathrm{TD}$ & $0 \%$ \\
\hline Norgestrel & TD & $0 \%$ & 0.00 & $0 \%$ & TD & $0 \%$ \\
\hline Simvastatin & 0.14 & $33 \%$ & 0.42 & $33 \%$ & $<$ LOQ & $13 \%$ \\
\hline
\end{tabular}

TD: Tidak dikesan

JADUAL 7. Kehadiran farmaseutik sasaran sepanjang tempoh persampelan air sungai $(n=15)$

\begin{tabular}{|c|c|c|c|c|c|c|}
\hline \multicolumn{7}{|c|}{ Kehadiran farmaseutik dalam air sungai $(n=15)$} \\
\hline \multirow[b]{2}{*}{ Farmaseutik } & \multicolumn{2}{|c|}{$\mathrm{S} 1$} & \multicolumn{2}{|c|}{$\mathrm{S} 2$} & \multicolumn{2}{|c|}{ S3 } \\
\hline & $\begin{array}{c}\operatorname{Max} \\
(\mu \mathrm{g} / \mathrm{L})\end{array}$ & $\begin{array}{c}\text { Kekerapan } \\
\text { dikesan }(\%)\end{array}$ & $\operatorname{Max}(\mu \mathrm{g} / \mathrm{L})$ & $\begin{array}{c}\text { Kekerapan } \\
\text { dikesan }(\%)\end{array}$ & $\begin{array}{c}\operatorname{Max} \\
(\mu g / L)\end{array}$ & $\begin{array}{c}\text { Kekerapan } \\
\text { dikesan }(\%)\end{array}$ \\
\hline Acetaminophen & 0.52 & $7 \%$ & 1.6 & $33 \%$ & 5.34 & $20 \%$ \\
\hline Theophylline & 2.14 & $73 \%$ & 2.91 & $73 \%$ & 2.62 & $67 \%$ \\
\hline Caffeine & 5.16 & $73 \%$ & 6.83 & $73 \%$ & 6.48 & $67 \%$ \\
\hline Metoprolol & 0.08 & $7 \%$ & 0.17 & $7 \%$ & 0.11 & $13 \%$ \\
\hline Sulfamethoxazole & TD & $0 \%$ & TD & $0 \%$ & TD & $0 \%$ \\
\hline Prednisolone & $\mathrm{TD}$ & $0 \%$ & TD & $0 \%$ & $\mathrm{TD}$ & $0 \%$ \\
\hline Carbamazepine & TD & $0 \%$ & 0.16 & $7 \%$ & TD & $0 \%$ \\
\hline Ketoprofen & 0.16 & $7 \%$ & 0.11 & $7 \%$ & 0.19 & $7 \%$ \\
\hline Norgestrel & 0.57 & $7 \%$ & 0.51 & $7 \%$ & 0.63 & $7 \%$ \\
\hline Simvastatin & 0.32 & $13 \%$ & 0.46 & $33 \%$ & 0.16 & $20 \%$ \\
\hline
\end{tabular}

TD: Tidak dikesan 


\section{KeSIMPULAN}

Kaedah analisis berdasarkan SPE diikuti dengan LC-TOF-MS menggunakan mod pengionan secara semburan elektro positif telah berjaya dibangunkan dan dioptimumkan untuk menentukan kehadiran sepuluh farmaseutik terpilih dalam persekitaran akuatik. Kaedah SPE tersebut melibatkan langkah pengekstrakan tunggal yang menggunakan isi padu sampel yang rendah iaitu sebanyak 100 $\mathrm{mL}$ dan pelarut elusi yang minimum. Keputusan kajian semasa menunjukkan bahawa masih terdapat sebahagian analit sasaran hadir dalam efluen STP seperti caffeine, theophylline, metroprolol, sulfamethoxazole dan carbamazepine. Acetaminophen dan caffeine kerap dijumpai dalam sampel STP belum dirawat, berbanding efluen STP. Ini menunjukkan bahawa bahan farmaseutik dapat disingkirkan dengan baik semasa proses rawatan di STP. Namun begitu kedua-dua caffeine dan acetaminophen serta beberapa analit yang lain masih lagi dijumpai dalam sungai berdekatan. Kajian semasa ini secara keseluruhannya telah membuktikan bahawa persekitaran akuatik di Malaysia terdedah kepada kehadiran bahan cemar farmaseutik.

\section{PENGHARGAAN}

Setinggi-tinggi penghargaan ditujukan kepada Pusat Pengurusan Penyelidikan dan Instrumentasi (CRIM), Universiti Kebangsaan Malaysia atas sokongan terhadap operasi LC-TOF-MS sepanjang penyelidikan ini dijalankan.

\section{RUJUKAN}

Albert, O., Desdoits-Lethimonier, C., Lesné, L., Legrand, A., Guillé, F., Bensalah, K., Dejucq-Rainsford, N. \& Jégou, B. 2013. Paracetamol, aspirin and indomethacin display endocrine disrupting properties in the adult human testis in vitro. Human Reproduction 28(7): 1890-1898.

Al-Odaini, N.A., Zakaria, M.P., Yaziz, M.I. \& Surif, S. 2010. Multi-residue analytical method for human pharmaceuticals and synthetic hormones in river water and sewage effluents by solid-phase extraction and liquid chromatography-tandem mass spectrometry. Journal of Chromatography A 1217(44): 6791-6806.

Al-Qaim,F.F., Abdullah, M.P., Othman, M.R., Latip, J. \& Zakaria, Z. 2014. Multi-residue analytical methodology-based liquid chromatography-time-of-flight-mass spectrometry for the analysis of pharmaceutical residues in surface water and effluents from sewage treatment plants and hospitals. Journal of Chromatography A 1345: 139-153.

Al-Qaim, F.F., Abdullah, M.P., Latip, J., Khalik, W.M.A.W.M., Tahrim, N.A., Abidin, N.A.Z. \& Othman, M.R. 2016. Detection of gliclazide in aqueous samples using liquid chromatography/time-of-flight/mass spectrometry. Sains Malaysiana 45(5): 803-810.

Bienkowski, B. 2015. Bacteria May Be Remaking Drugs in Sewage. Environmental Health News. https://www. scientificamerican.com/article/bacteria-may-be-remakingdrugs-in-sewage/. Diakses pada 20 April 2017.

González-Barreiro, C., Lores, M., Casais, M.C. \& Cela, R. 2003. Simultaneous determination of neutral and acidic pharmaceuticals in wastewater by high-performance liquid chromatography-post-column photochemically induced fluorimetry. Journal of Chromatography A 993(1-2): 29-37.

Gros, M., Petrovic, M. \& Barceló, D. 2006. Development of a multi-residue analytical methodology based on liquid chromatography-tandem mass spectrometry (LC-MS/MS) for screening and trace level determination of pharmaceuticals in surface and wastewaters. Talanta 70(4): 678-690.

Lavén, M., Alsberg, T., Yu, Y., Adolfsson-Erici, M. \& Sun, H. 2009. Serial mixed-mode cation- and anion-exchange solid-phase extraction for separation of basic, neutral and acidic pharmaceuticals in wastewater and analysis by highperformance liquid chromatography-quadrupole time-offlight mass spectrometry. Journal of Chromatography A 1216(1): 49-62.

Ministry of Health Malaysia (MOH). 2014. Malaysian Statistics on Medicine 2009-2010. The National Medicines Use Survey.

National Essential Drug List (NEDL). 3rd ed. 2012. http://www. pharmacy.gov.my/v2/sites/default/files/document-upload/ nedl-only-list publish-website.pdf.

Oropesa, A.L., Floro, A.M. \& Palma, P. 2016. Assessment of the effects of the carbamazepine on the endogenous endocrine system of Daphnia magna. Environmental Science and Pollution Research 23(17): 17311-17321.

Petrovic, M., Gros, M. \& Barcelo, D. 2006. Multi-residue analysis of pharmaceuticals in wastewater by ultra-performance liquid chromatography-quadrupole-time-of-flight mass spectrometry. Journal of Chromatography A 1124(1-2): $68-81$

Sanagi, M.M., Mokhtar, S.U., Ibrahim, W.A.W. \& AboulEnein, H.Y. 2013. Application of dispersive liquid-liquid microextraction based on solidification of floating organic droplet to the analysis of antidepressant drugs in water samples. Sains Malaysiana 42(2): 149-157.

Tan, E.S.S., Ho, Y.B., Zakaria, M.P., Abdul Latif, P. \& Saari, N. 2015. Simultaneous extraction and determination of pharmaceuticals and personal care products (PPCPs) in river water and sewage by solid-phase extraction and liquid chromatography-tandem mass spectrometry. International Journal of Environmental Analytical Chemistry 95(9): 816-832.

U.S. EPA. 2008. Pharmaceuticals and Personal Care Products (PCPPs). http://water.epa.gov/scitech/swguidance/ppcp/ index.cfm. Diakses pada 3 Ogos 2016.

Vanderford, B.J.\& Snyder,S.A. 2006.Analysis of pharmaceuticals in water by isotope dilution liquid chromatography/tandem mass spectrometry. Environmental Science and Technology 40(23): 7312-7320

Vieno, N.M., Tuhkanen, T. \& Kronberg, L. 2006. Analysis of neutral and basic pharmaceuticals in sewage treatment plants and in recipient rivers using solid phase extraction and liquid chromatography-tandem mass spectrometry detection. Journal of Chromatography A 1134: 101-111.

Nurfaizah Abu Tahrim*

Pusat Pengajian Sains Kimia \& Teknologi Makanan

Fakulti Sains dan Teknologi

Universiti Kebangsaan Malaysia

43600 UKM Bangi, Selangor Darul Ehsan

Malaysia 
Nurfaizah Abu Tahrim*

Pusat Penyelidikan dan Analisis Air (ALIR)

Fakulti Sains dan Teknologi

Universiti Kebangsaan Malaysia

43600 UKM Bangi, Selangor Darul Ehsan

Malaysia

Md. Pauzi Abdullah

Akademi Sains Malaysia

Tingkat 20, Sayap Barat

Menara MATRADE

Jalan Sultan Haji Ahmad Shah

50480 Kuala Lumpur, Wilayah Persekutuan Malaysia
*Pengarang untuk surat-menyurat; email:nfaizah@ukm.edu.my

Diserahkan: 16 September 2017

Diterima: $\quad 2$ Januari 2018 